\title{
Papers
}

\section{Impact on survival of intensive follow up after curative resection for colorectal cancer: systematic review and meta-analysis of randomised trials}

\author{
Andrew G Renehan, Matthias Egger, Mark P Saunders, Sarah T O’Dwyer
}

\begin{abstract}
Objective To review the evidence from clinical trials of follow up of patients after curative resection for colorectal cancer.

Design Systematic review and meta-analysis of randomised controlled trials of intensive compared with control follow up.

Main outcome measures All cause mortality at five years (primary outcome). Rates of recurrence of intraluminal, local, and metastatic disease and metachronous (second colorectal primary) cancers (secondary outcomes).

Results Five trials, which included 1342 patients, met the inclusion criteria. Intensive follow up was associated with a reduction in all cause mortality (combined risk ratio $0.81,95 \%$ confidence interval 0.70 to $0.94, \mathrm{P}=0.007)$. The effect was most pronounced in the four extramural detection trials that used computed tomography and frequent measurements of serum carcinoembryonic antigen (risk ratio $0.73,0.60$ to $0.89, \mathrm{P}=0.002$ ). Intensive follow up was associated with significantly earlier detection of all recurrences (difference in means 8.5 months, 7.6 to 9.4 months, $\mathrm{P}<0.001)$ and an increased detection rate for isolated local recurrences (risk ratio $1.61,1.12$ to $2.32, \mathrm{P}=0.011$ ).

Conclusions Intensive follow up after curative resection for colorectal cancer improves survival. Large trials are required to identify which components of intensive follow up are most beneficial.
\end{abstract}

\section{Introduction}

Colorectal cancer is the second most common malignancy in Western societies and the second leading cause of death related to cancer. ${ }^{1}$ At the time of initial diagnosis, about two thirds of patients undergo resection with curative intent, but $30-50 \%$ of these patients will relapse and die of their disease. ${ }^{2}$ Some authors have postulated that intensive follow up would lead to early detection of recurrent disease or metachronous (second colorectal primary) tumours, or both, and thus improve survival, while others have questioned the need for follow up at all. ${ }^{3}$ This is reflected in current UK guidelines for the management of patients with colorectal cancer, which state that there is "no evidence" of survival benefit with intensive follow up $^{4}$ or that it is "not worth while." There is currently wide variation in follow up. ${ }^{6-8}$ For example, the Wales and Trent audits reported that among colorectal and gastrointestinal surgeons, $57 \%$ included the use of colonoscopy in their surveillance programme at a frequency of three times over five years to annually. Furthermore, some 13\% of gastrointestinal surgeons offered no routine testing at all. ${ }^{6}$ Among these many different protocols, the costs to health services are considerable and need to be justified with evidence.

Several randomised controlled trials have addressed this issue, but none had sufficient statistical power. Two meta-analyses on studies of follow up after treatment of colorectal cancer have been published, but one was based entirely on non-randomised data ${ }^{9}$ and the other on combined randomised trials with cohort studies. ${ }^{10}$ We carried out a systematic review and meta-analysis of randomised clinical trials to determine whether there is any benefit of intensive follow up strategies after curative resection for colorectal cancer.

\section{Methods}

Search strategy-Using Cochrane methodology ${ }^{11}$ we searched Medline, Embase, CANCERLIT, and the Cochrane controlled trials register for relevant studies (box 1). We considered trials in any language. We supplemented electronic searches by hand searching reference lists, reviews, and abstracts from meetings. National trial registers were also searched for unpublished trials. In addition, we contacted the editorial base of the Cochrane colorectal cancer group.

Inclusion and exclusion criteria-We evaluated each trial for inclusion in the meta-analysis on the basis of four criteria: study design (randomised controlled trial), target population (patients with colorectal cancer treated surgically with curative intent), timing of randomisation (at or shortly after surgery), and availability of survival data related to cancer. We included studies that compared intensive follow up strategies with control follow up regimens, as defined by the individual trials. We excluded studies that included patients with advanced disease (Dukes' stage $\mathrm{D})$, when curative resection is generally not possible.

\author{
Department of \\ Surgery, Christie \\ Hospital NHS \\ Trust, Manchester \\ M20 4BX \\ Andrew G Renehan \\ senior research fellow \\ Sarah T O'Dwyer \\ consultant surgeon \\ MRC Health \\ Services Research \\ Collaboration, \\ Department of \\ Social Medicine, \\ University of \\ Bristol, Bristol \\ BS8 2PR \\ Matthias Egger \\ professor in \\ epidemiology and \\ public health medicine \\ Department of \\ Clinical Oncology, \\ Christie Hospital \\ NHS Trust, \\ Manchester \\ Mark P Saunders \\ consultant clinical \\ oncologist \\ Correspondence to: \\ A Renehan \\ arenehan@ \\ picr.man.ac.uk
}

BMJ 2002;324:1-8 


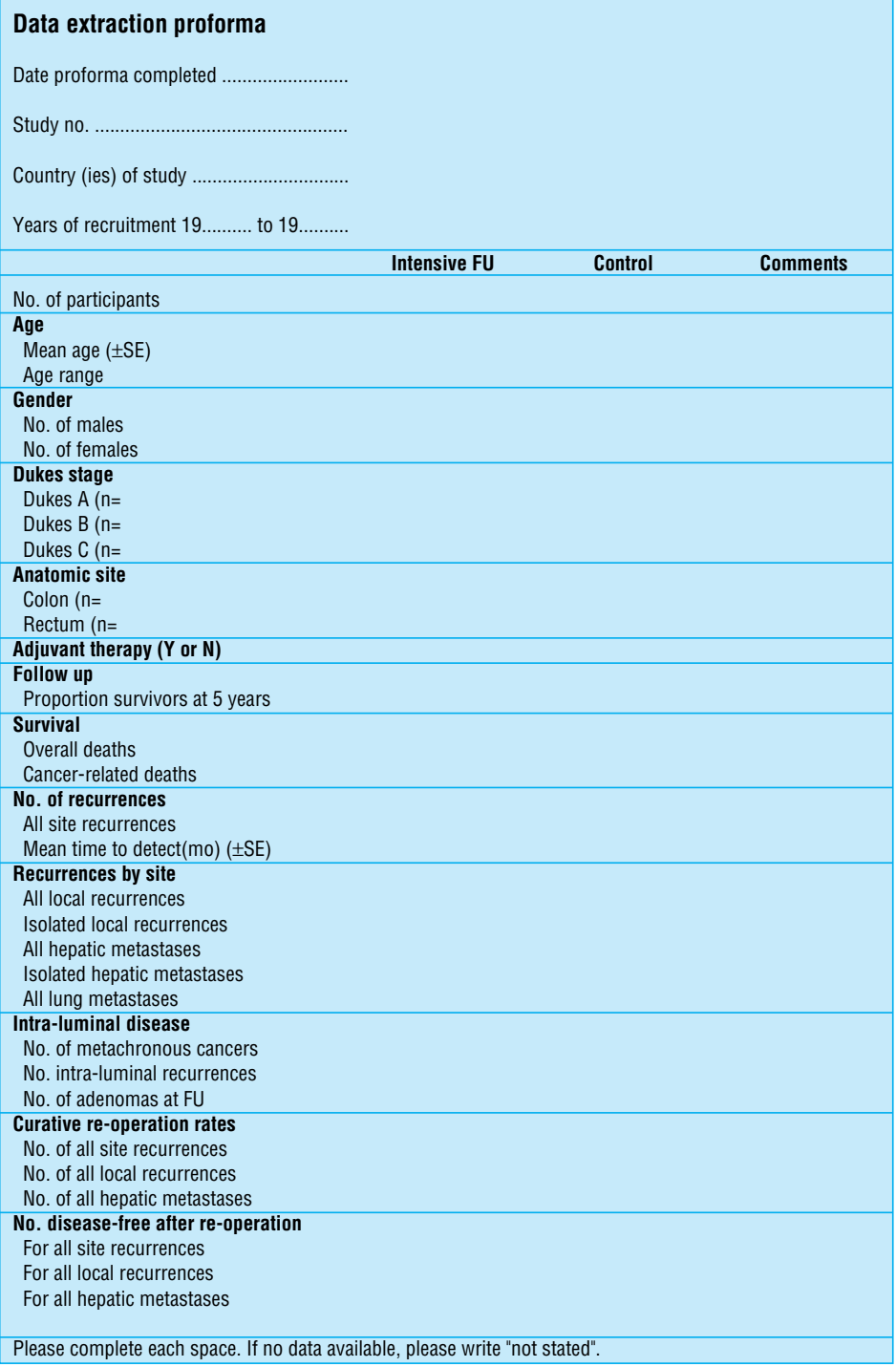

Fig 1 Form for data extraction

Data extraction - The data were extracted independently by two investigators (AGR and MPS), with disagreements resolved by a third reviewer (STO'D) (fig 1). Data were extracted from the final report for each trial, but preliminary reports were also consulted for additional details on methods.

Outcome measures-The primary outcome was all cause mortality at five years. Secondary outcomes were total number of recurrences, any type of local recurrences, isolated local recurrences, any hepatic metastases, isolated hepatic metastases, lung metastases, intraluminal recurrences, and metachronous (second colorectal primary) cancers.

Assessment of methodological quality-Two of us (AGR and ME) independently assessed adequacy of concealment of patients' allocation to treatment groups, double blinding, and withdrawals. ${ }^{12}$ Differences in assessments were resolved by consensus.

Subgroup analysis-Different diagnostic tests were used during follow up in different trials. We performed a subgroup analysis based on the a priori hypothesis that the early detection of extramural recurrent disease (namely, local pelvic recurrences and solitary hepatic metastases), with investigations such as computed tomography or frequent measurements of serum carcinoembryonic antigen (at least every three months for two years and then every six months thereafter), or both, was more likely to be effective in improving survival related to cancer than strategies directed only at the detection of intraluminal disease (such as the use of colonoscopy). ${ }^{6}$

Statistical analysis-We have expressed the main results as combined risk ratios with the fixed effects method and performed tests for heterogeneity. ${ }^{13}$ We combined data on the duration to first relapse using differences in means. ${ }^{13}$ We also performed random effects methods for comparison. ${ }^{14}$ We examined publication bias and related biases in funnel plots and carried out a test of funnel plot asymmetry. ${ }^{15}$ Sensitivity analyses included assessment of the influence of year of publication, mean ages in trial groups, and Dukes' stages with meta-regression techniques. ${ }^{16}$ All analyses were performed in Stata version 7.0 (Stata Corporation, College Station, TX, USA).

\section{Results}

Figure 2 shows the summary profile of the search. We identified seven potentially eligible randomised controlled trials, ${ }^{17-23}$ five of which met our inclusion criteria. $^{17-21}$ Two trials reported preliminary results ${ }^{24}$; two also published on related topics. ${ }^{26-28}$ We also identified six ongoing trials or trials in preparation (box 2). We excluded the study by Northover et al because participants with a raised carcinoembryonic antigen con-

Box 1 Search methods

Bibliographic databases (to April 2001)

- Medline (SilverPlatter)

- Embase (Ovid)

- CANCERLIT (Ovid)

- Cochrane controlled trials register (issue 1: 2001)

- MESH terms "colorectal neoplasm," "colonic neoplasm," "rectal neoplasm," "follow-up," "surveillance"

Reference lists

- Selected articles, review articles, and commentaries Hand searched meeting proceedings

- American Gastroenterology Association (1996-2001)

- American Society for Cancer Research (1996-2001)

- American Society for Colon and Rectal Surgeons (1996-2001)

National trial registries

- United Kingdom National Research Register of ongoing health research (www.doh.gov.uk/research/ nrr.htm)

- Computer Retrieval of Information on Scientific Projects (CRISP) database (www-commons.cit.nih.gov/ crisp)

- Current Science register of controlled trials (www.controlled-trials.com)

- US cancer-specific register of controlled trials (www.nci.nih.gov/search/clinical_trials/)

- British Journal of Surgery Scientific Surgery Archive of meta-analyses and randomised controlled trials (www.bjs.co.uk/searchSSurgery.asp) 


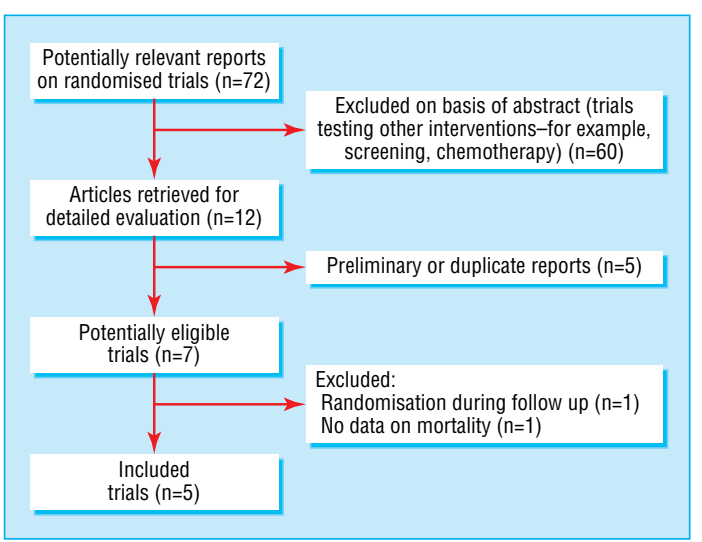

Fig 2 Summary of systematic review profile

centration were randomised during follow up rather than at the time of surgery. ${ }^{22}$ We also excluded the study by Barillari et al because randomisation was limited to less than half the participants, and the main outcome measured was the number of metachronous colorectal tumours detected rather than survival. ${ }^{23}$

\section{Study characteristics}

The five included trials comprised 1342 participants: 666 assigned to intensive follow up and 676 assigned to control. Table 1 shows the baseline characteristics of the participants enrolled in these trials. In the trial by Makela et al patients in the intensive group were on average six years younger than those in the control group. ${ }^{17}$ In two other trials there were smaller age

Box 2 Randomised trials in preparation or ongoing

UKCCCR Colorectal Cancer Group: To compare the value of intensive versus minimalist follow up after apparently curative resection for colorectal cancer on disease free and overall survival (ukcccr.icnet.uk/ groups/colohome.html) and McArdle C, ABC of colorectal cancer: effectiveness of follow up. BMJ 2000;321:1332:5

Libutti S. A prospective trial of CT, MRI, PET scanning and antibody scanning in patients with colorectal cancer and rising CEA (www.cybercable.tm.fr/ $\sim$ biblioa/arcach2.html)

Southampton and Wessex Colorectal Cancer Group. A randomised controlled trial to assess the cost effectiveness of intensive versus no scheduled follow up in patients who have undergone resection for colorectal cancer with curative intent (personal communication with Professor J Primrose, University of Southampton)

A randomised trial of intensive versus minimalist follow up of patients with resected Dukes B-C colorectal cancer: the pilot phase. GILDA (Gruppo Italiano di Lavoro per la Diagnosi Anticipata). Tumori 1998;84(suppl):89(abstr 221)

Catalan Agency for Health Technology Assessment (CAHTA): Patients' monitoring and follow up in colorectal cancer with the purpose of detecting curable tumour relapses (cited in the Cochrane Library, 2000, issue 2)

FFCD (Foundation Francaise de Cancerologie Digestive) colorectal cancer follow up study (cited in: Audisio RA, Robertson C, Colorectal cancer follow up: perspectives for future studies. Eur J Surg Oncol 2000;26:329-37) differences in the same direction. ${ }^{19}{ }^{20}$ There was an imbalance in the sex distribution in one trial. ${ }^{18}$ All but one study ${ }^{20}$ included patients with Dukes' stage A disease. The proportion of patients with Dukes' stage C disease was higher in the control group than in the intensive group in two trials, ${ }^{19}{ }^{21}$ whereas the opposite was the case in another trial. ${ }^{18}$ The study periods predated the widespread use of adjuvant chemotherapy, and only one study used adjuvant radiotherapy for rectal cancers. ${ }^{20}$

The tests and the frequency of their use varied considerably (table 2 ). ${ }^{2}$ No study directly compared specific tests, but in four trials computed tomography and frequent measurements of carcinoembryonic antigen were limited to the intensive arms. ${ }^{17-20}$ We characterised these trials as the extramural detection group. The Danish study focused heavily on the increased detection of intraluminal disease and thus formed the intramural detection group. ${ }^{21}$

\section{Methodological quality of trials}

In general methods were poorly reported. Two trials randomised patients by open cards or random number tables. ${ }^{19}{ }^{20}$ Randomisation was stratified by site and Dukes' stage in two trials, ${ }^{19-21}$ but block sizes were not reported. Blinding of clinicians or assessors was not mentioned except for one trial, which reported that computed tomograms were evaluated by an "independent radiologist." ${ }^{\prime 9}$ Completeness of follow up among survivors was good, with $100 \%$ at five years in three studies (table 2).

\section{All cause mortality}

Data on all cause mortality were available in all studies. Data on mortality related to cancer were available in only two studies. ${ }^{18}{ }^{21}$ At five years, 197 of 666 patients $(30 \%)$ allocated to intensive follow up and 247 of $676(37 \%)$ allocated to control groups had died. By the fixed effects method, the combined risk ratio was $0.81(95 \%$ confidence interval 0.70 to $0.94, \mathrm{P}=0.007$ ) in favour of intensive follow up (fig 3). Similar values for risk ratios were estimated by the

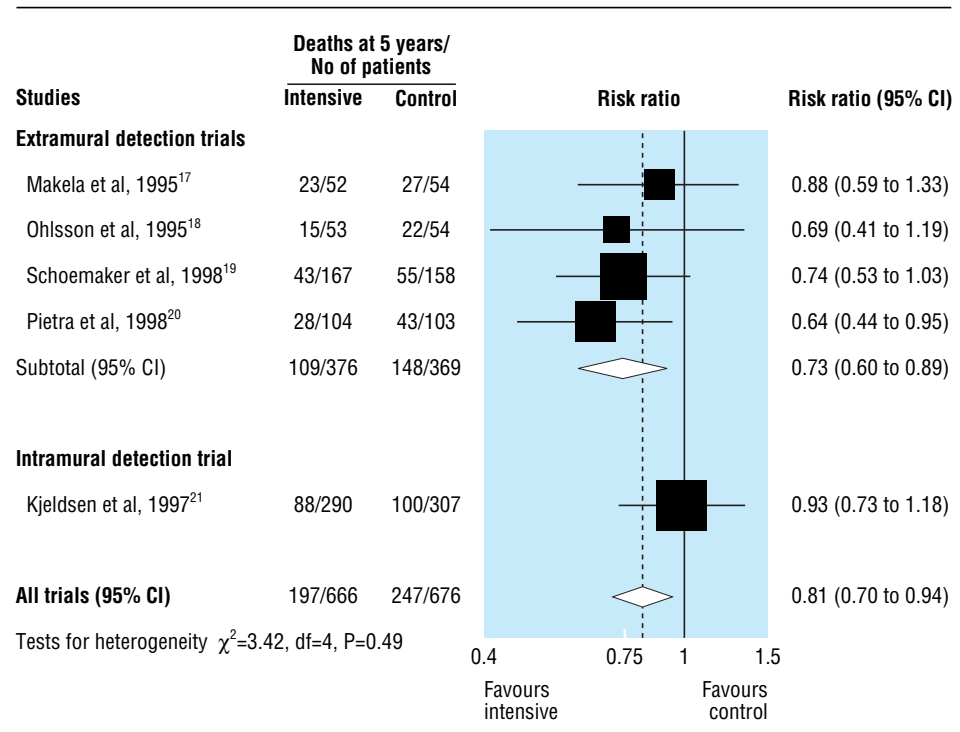

Fig 3 Pooled analysis with summary estimates (fixed effects method) for five year survival: data categorised into detection groups in accordance with a priori hypothesis (see methods) 
Table 1 Baseline characteristics of five randomised trials on follow up after curative resection for colorectal cancer

\begin{tabular}{|c|c|c|c|c|c|c|c|c|c|c|}
\hline \multirow[b]{2}{*}{ Study } & \multicolumn{2}{|c|}{ No of patients } & \multicolumn{2}{|c|}{$\begin{array}{c}\text { Mean }\left(\mathrm{SD}^{*}\right) \text { age } \\
\text { (years) }\end{array}$} & \multicolumn{2}{|c|}{ Men/women } & \multicolumn{2}{|c|}{ Colon/rectum } & \multicolumn{2}{|c|}{ Dukes' stage $(A / B / C)$} \\
\hline & Intensive & Control & Intensive & Control & Intensive & Control & Intensive & Control & Intensive & Control \\
\hline \multicolumn{11}{|c|}{ Extramural detection trials } \\
\hline Makela et al, $1995^{17}$ & 52 & 54 & $63(9)$ & $69(8)$ & $25 / 27$ & $27 / 27$ & $36 / 16$ & $39 / 15$ & $13 / 24 / 15$ & $15 / 24 / 15$ \\
\hline Ohlsson et al, $1995^{18}$ & 53 & 54 & $66(9)$ & $66(9)$ & $20 / 33$ & $31 / 23$ & $34 / 19$ & 3717 & $10 / 21 / 22$ & $9 / 26 / 19$ \\
\hline $\begin{array}{l}\text { Schoemaker et al, } \\
1998^{19}\end{array}$ & 167 & 158 & $67(9)$ & $69(7)$ & 109/58 & $98 / 60$ & $121 / 46$ & $117 / 41$ & $41 / 79 / 47$ & $30 / 74 / 54$ \\
\hline Pietra et al, $1998^{20}$ & 104 & 103 & $62(12)$ & $64(9)$ & $56 / 46$ & $53 / 50$ & $73 / 31$ & $66 / 37$ & $0 / 62 / 42$ & $0 / 60 / 43$ \\
\hline \multicolumn{11}{|c|}{ Intramural detection trial } \\
\hline Kjeldsen et al, $1997^{21}$ & 290 & 307 & $64(6)$ & $64(6)$ & $168 / 122$ & $158 / 149$ & $156 / 134$ & $158 / 149$ & $68 / 148 / 74$ & $70 / 145 / 92$ \\
\hline
\end{tabular}

Table 2 Detailed characteristics of surveillance programmes used in five randomised trials of intensive versus control follow up of patients after curative resection for colorectal cancer

\begin{tabular}{|c|c|c|}
\hline Study & Intensive follow up & Control follow up \\
\hline $\begin{array}{l}\text { hakela et al, } \\
1995^{17}\end{array}$ & $\begin{array}{l}\text { Seen in clinic } 3 \text { monthly for first } 2 \text { years, then } 6 \text { monthly: physical } \\
\text { examination, full blood count, faecal occult blood test, carcinoembryonic } \\
\text { antigen levels, and chest } x \text { ray. Yearly colonoscopy. Sigmoidoscopy } 3 \text { monthly } \\
\text { for rectal and sigmoid cancers. Ultrasonography of liver } 6 \text { monthly. Computed } \\
\text { tomography yearly. All followed up to } 5 \text { years }\end{array}$ & $\begin{array}{l}\text { Seen in clinic } 3 \text { monthly for first } 2 \text { years, then } 6 \text { monthly: physical } \\
\text { examination, full blood count, faecal occult blood test, } \\
\text { carcinoembryonic antigen levels, and chest } x \text { ray. Yearly barium } \\
\text { enema. Rigid sigmoidoscopy } 3 \text { monthly for rectal cancers. All } \\
\text { followed up to } 5 \text { years }\end{array}$ \\
\hline $\begin{array}{r}\text { Ohlsso } \\
\text { al, } 1\end{array}$ & $\begin{array}{l}\text { Seen in clinic } 3 \text { monthly for the first } 2 \text { years, then } 6 \text { monthly: physical } \\
\text { examination, rigid proctosigmoidoscopy, liver function tests, carcinoembryonic } \\
\text { antigen levels, faecal occult blood test, chest } x \text { ray. Colonoscopy at } 3,15,30 \text {, } \\
\text { and } 60 \text { months, computed tomography after abdominoperineal resection at } 3 \text {, } \\
6,12,18 \text {, and } 24 \text { months. All followed up to } 5 \text { years }\end{array}$ & $\begin{array}{l}\text { No systematic follow up. Patients were instructed to leave samples } \\
\text { for faecal occult blood test testing every third month during the first } \\
2 \text { years and then every year. All accounted for to } 5 \text { years }\end{array}$ \\
\hline $\begin{array}{l}\text { Schoemaker } \\
\text { et al, } \\
1998^{19}\end{array}$ & $\begin{array}{l}\text { Seen in clinic } 3 \text { monthly for first } 2 \text { years, then } 6 \text { monthly for } 5 \text { years; physical } \\
\text { examination, full blood count, liver function tests, and Haemoccult II. Yearly } \\
\text { chest } x \text { ray and computed tomography of liver. Yearly colonoscopy. } \\
\text { Carcinoembryonic antigen measurements were performed but not used to } \\
\text { trigger further examinations. } 94 \% \text { followed up to } 5 \text { years }\end{array}$ & $\begin{array}{l}\text { Seen in clinic } 3 \text { monthly for first } 2 \text { years, then } 6 \text { monthly for } 5 \\
\text { years; physical examination, full blood count, liver function tests, } \\
\text { carcinoembryonic antigen levels, and Haemoccult II. } \\
\text { Carcinoembryonic antigen measurements were performed but not } \\
\text { used to trigger further examinations. } 95 \% \text { followed up to } 5 \text { years }\end{array}$ \\
\hline $\begin{array}{l}\text { Pietra et al, } \\
1998^{20}\end{array}$ & $\begin{array}{l}\text { Seen in clinic } 3 \text { monthly for first } 2 \text { years, then } 6 \text { monthly for next } 3 \text { years, } \\
\text { thereafter yearly; physical examination, ultrasonography of liver, } \\
\text { carcinoembryonic antigen levels. Yearly colonoscopy, chest } x \text { ray, and } \\
\text { computed tomography. All followed up to } 5 \text { years }\end{array}$ & $\begin{array}{l}\text { Seen in clinic } 6 \text { monthly for first year, then yearly; physical } \\
\text { examination, ultrasonography of liver, carcinoembryonic antigen } \\
\text { levels. Yearly colonoscopy and chest } x \text { ray. All followed up to } 5 \\
\text { years }\end{array}$ \\
\hline $\begin{array}{l}\text { jeldsen et } \\
\text { al, } 1997^{21}\end{array}$ & $\begin{array}{l}\text { Physical examination, digital rectal examination, gynaecological examination, } \\
\text { Haemoccult-II, colonoscopy, chest } x \text { ray, full blood count, erythrocyte } \\
\text { sedimentation rate, liver function tests, at } 6 \text { monthly in first } 3 \text { years, then } 12 \\
\text { monthly for next } 2 \text { years, then } 5 \text { yearly. } 79 \% \text { followed up to } 5 \text { years }\end{array}$ & $\begin{array}{l}\text { Physical examination, digital rectal examination, gynaecological } \\
\text { examination, Haemoccult-II, colonoscopy, chest } x \text { ray, full blood } \\
\text { count, erythrocyte sedimentation rate, liver function tests, at } 5 \text { and } \\
10 \text { years. } 73 \% \text { followed up to } 5 \text { years }\end{array}$ \\
\hline
\end{tabular}

random effects method (table 3). There was no significant heterogeneity.

The effect on mortality was most pronounced in the four extramural detection trials that used computed tomography and frequent measurements of serum carcinoembryonic antigen (combined risk ratio $0.73,0.60$ to $0.89, \mathrm{P}=0.002$ ). The five year mortality in the control groups ranged from $35 \%$ to $50 \%$, which translates into an absolute reduction in mortality of $9 \%$ to $13 \%$ or a number needed to treat (the number of patients needed to prevent one death) of eight to 11 . Little effect was seen in the Danish trial, which used only investigations to detect intramural disease (risk ratio $0.93,0.73$ to $1.18, \mathrm{P}=0.88$ ).

\section{Recurrences, metastases, and metachronous cancers}

There were no differences in rates of recurrence in all sites between the two groups: 212/666 (32\%) for intensive versus 224/676 (33\%) for control follow up. However, recurrences were detected 8.5 months (95\% confidence interval 7.6 to 9.4 months) earlier with intensive follow up (table 4). Subgroup analysis in accordance with the a priori hypothesis revealed no distinct patterns.

The detection rates for all local recurrences and all hepatic and lung metastases were similar in the two groups (fig 4, table 3). However, on the basis of data from three trials, intensive follow up was associated with a significant increase in detection of isolated local recurrences $(15 \%$ v $9 \%$ : risk ratio $1.61,1.12$ to 2.32 , $\mathrm{P}=0.011$ ). Intensive follow up was also associated with a small non-significant increase in detection of hepatic metastases. Overall, rates of intraluminal recurrence and detection of metachronous cancer were low (3.2\% and $1.3 \%$, respectively), and there were no differences between follow up regimens.

\section{Sensitivity analysis}

We found no influence of year of commencement or publication, mean age, or proportion of Dukes' stage C cancers on any outcome $(\mathrm{P}>0.10)$. There was no clear evidence of funnel plot asymmetry in any analysis $(\mathrm{P}>0.10)$

\section{Discussion}

The findings of this systematic review and metaanalysis of randomised controlled trials support the view that intensive follow up after curative resection for colorectal cancer improves survival at five years.

\section{Survival benefit}

This is the strongest evidence to date to show the beneficial effects of intensive follow up. Individual trials have been inconclusive, probably because of small sample sizes. Our analysis shows that using modern follow up regimens (including computed tomography or frequent measurements of serum carcinoembryonic antigen, or both) there was an absolute reduction in 
Table 3 Details of summary effects for various end points in patients with colorectal cancer according to intensive or control follow up. Figures are numbers (percentage) of patients and risk ratios $(95 \%$ confidence interval)

\begin{tabular}{|c|c|c|c|c|}
\hline & Intensive follow up & Control follow up & Fixed effects* & Random effects $\dagger$ \\
\hline \multicolumn{5}{|l|}{ All cause mortality } \\
\hline Makela et al, $1995^{17}$ & $23 / 52(44)$ & $27 / 54(50)$ & 0.88 (0.59 to 1.33$)$ & \\
\hline Ohlsson et al, $1995^{18}$ & $15 / 53(28)$ & $22 / 54(41)$ & 0.69 (0.41 to 1.19$)$ & \\
\hline Schoemaker et al, $1998^{19}$ & $43 / 167(26)$ & $55 / 158(35)$ & $0.74(0.53$ to 1.03$)$ & \\
\hline Pietra et al, $1998^{20}$ & $28 / 104(27)$ & $43 / 103(42)$ & 0.64 (0.44 to 0.95$)$ & \\
\hline Subgroup $\ddagger$ & 109/376 (29) & $148 / 369(40)$ & $0.73(0.60$ to 0.89$)$ & $0.74(0.61$ to 0.91$)$ \\
\hline Kjeldsen et al, $1997^{21}$ & $88 / 290(30)$ & 100/307 (33) & 0.93 (0.73 to 1.18$)$ & \\
\hline Pooled effect§ & 197/666 (30) & $247 / 676(27)$ & 0.81 (0.70 to 0.94$)$ & 0.81 (0.68 to 0.96$)$ \\
\hline \multicolumn{5}{|l|}{ All site recurrences } \\
\hline Makela et al, $1995^{17}$ & $22 / 52(42)$ & $21 / 54(39)$ & 1.09 (0.69 to 1.73$)$ & \\
\hline Ohlsson et al, $1995^{18}$ & $17 / 53(32)$ & $18 / 54(33)$ & 0.96 (0.56 to 1.66$)$ & \\
\hline Schoemaker et al, $1998^{19}$ & $56 / 167(34)$ & $64 / 158(41)$ & 0.83 (0.62 to 1.10$)$ & \\
\hline Pietra et al, $1998^{20}$ & 41/104 (39) & $41 / 103(40)$ & 0.99 (0.71 to 1.39$)$ & \\
\hline Subgroup $\ddagger$ & $136 / 376(36)$ & $144 / 367$ (39) & $0.93(0.77$ to 1.12$)$ & 0.93 (0.77 to 1.12$)$ \\
\hline Kjeldsen et al, $1997^{21}$ & $76 / 290(26)$ & $80 / 307(26)$ & 1.01 (0.77 to 1.32$)$ & \\
\hline Pooled effect§ & 212/666 (32) & $224 / 676(33)$ & 0.95 (0.82 to 1.11$)$ & 0.95 (0.82 to 1.11$)$ \\
\hline \multicolumn{5}{|l|}{ All local recurrences } \\
\hline Makela et al, $1995^{17}$ & $10 / 52(19)$ & 9/54 (17) & 1.15 (0.51 to 2.61$)$ & \\
\hline Ohlsson et al, $1995^{18}$ & $11 / 53(21)$ & $8 / 54(15)$ & 1.40 (0.61 to 3.21$)$ & \\
\hline Schoemaker et al, $1998^{19}$ & $7 / 167(4)$ & $11 / 158(7)$ & 0.60 (0.24 to 1.51$)$ & \\
\hline Pietra et al, $1998^{20}$ & $26 / 104(25)$ & 20/103 (19) & 1.29 (0.77 to 2.16$)$ & \\
\hline Subgroup $\ddagger$ & $54 / 376(14)$ & 48/367 (13) & 1.12 (0.79 to 1.52$)$ & $1.14(0.80$ to 1.63$)$ \\
\hline Kjeldsen et al, $1997^{21}$ & $49 / 290(17)$ & $42 / 307(14)$ & $1.24(0.84$ to 1.81$)$ & \\
\hline Pooled effect§ & 103/666 (15) & 90/676 (13) & 1.17 (0.91 to 1.52$)$ & 1.19 (0.91 to 1.54$)$ \\
\hline \multicolumn{5}{|l|}{ Isolated local recurrences } \\
\hline Makela et al, $1995^{17}$ & $3 / 52(6)$ & $2 / 54(4)$ & 1.56 (0.27 to 8.95$)$ & \\
\hline Ohlsson et al, $1995^{18}$ & \multicolumn{2}{|c|}{ Not stated } & & \\
\hline Schoemaker et al, $1998^{19}$ & \multicolumn{2}{|c|}{ Not stated } & & \\
\hline Pietra et al, $1998^{20}$ & 20/104 (19) & $8 / 103(8)$ & 2.48 (1.14 to 5.37$)$ & \\
\hline Subgroup $\ddagger$ & $23 / 156(15)$ & $10 / 157(6)$ & 2.30 (1.13 to 4.64$)$ & 2.30 (1.13 to 4.66$)$ \\
\hline Kjeldsen et al, $1997^{21}$ & $42 / 290(14)$ & $32 / 307(10)$ & 1.39 (0.90 to 2.14$)$ & \\
\hline Pooled effect§ & $65 / 446(15)$ & $42 / 464(9)$ & 1.61 (1.12 to 2.32$)$ & 1.59 (1.10 to 2.30$)$ \\
\hline \multicolumn{5}{|l|}{ All hepatic metastases } \\
\hline Makela et al, $1995^{17}$ & $5 / 52(10)$ & $2 / 54(4)$ & 2.60 (0.53 to 12.8$)$ & \\
\hline Ohlsson et al, $1995^{18}$ & $3 / 53(6)$ & $7 / 54(13)$ & $0.44(0.12$ to 1.60$)$ & \\
\hline Schoemaker et al, $1998^{19}$ & 20/167 (12) & $23 / 158(15)$ & 0.82 (0.47 to 1.44$)$ & \\
\hline Pietra et al, $1998^{20}$ & $21 / 104(20)$ & $32 / 103(31)$ & $0.65(0.40$ to 1.05$)$ & \\
\hline Subgroup $\ddagger$ & 49/376 (13) & $64 / 367(17)$ & 0.75 (0.53 to 1.05$)$ & $0.74(0.50$ to 1.10$)$ \\
\hline Kjeldsen et al, $1997^{21}$ & $22 / 290(8)$ & $27 / 307(9)$ & 0.86 (0.50 to 1.48$)$ & \\
\hline Pooled effect§ & $71 / 666(11)$ & $91 / 676(13)$ & 0.78 (0.59 to 1.05$)$ & 0.77 (0.58 to 1.03$)$ \\
\hline \multicolumn{5}{|l|}{ Isolated hepatic metastases } \\
\hline Makela et al, $1995^{17}$ & $2 / 52(4)$ & $0 / 54(0)$ & $5.19(0.26$ to 105$)$ & \\
\hline Ohlsson et al, $1995^{18}$ & \multicolumn{2}{|c|}{ Not stated } & & \\
\hline Schoemaker et al, $1998^{19}$ & $14 / 167(8)$ & $12 / 158(8)$ & 0.95 (0.47 to 1.92) & \\
\hline Pietra et al, $1998^{20}$ & $4 / 104(4)$ & $3 / 103(3)$ & $1.32(0.30$ to 5.75$)$ & \\
\hline Subgroup $\ddagger$ & $20 / 323(6)$ & $15 / 315(5)$ & 1.13 (0.61 to 2.08$)$ & 1.02 (0.51 to 2.02) \\
\hline Kjeldsen et al, $1997^{21}$ & \multicolumn{2}{|c|}{ Not stated } & & \\
\hline Pooled effect§ & $20 / 323(6)$ & $15 / 315(5)$ & 1.13 (0.61 to 2.08$)$ & 1.02 (0.51 to 2.02) \\
\hline \multicolumn{5}{|l|}{ All lung metastases } \\
\hline Makela et al, $1995^{17}$ & $1 / 52(2)$ & $3 / 54(6)$ & 0.35 (0.04 to 3.22$)$ & \\
\hline Ohlsson et al, $1995^{18}$ & $3 / 53(6)$ & $2 / 54(4)$ & $1.53(0.27$ to 8.78$)$ & \\
\hline Schoemaker et al, $1998^{19}$ & $8 / 167$ (5) & $10 / 158(6)$ & 0.76 (0.31 to 1.87$)$ & \\
\hline Pietra et al, $1998^{20}$ & $0 / 104(0)$ & $1 / 103(1)$ & 0.33 (0.01 to 8.01$)$ & \\
\hline Subgroup $\ddagger$ & $12 / 376(3)$ & $16 / 367(4)$ & 0.74 (0.36 to 1.51$)$ & 0.75 (0.36 to 1.08$)$ \\
\hline Kjeldsen et al, $1997^{21}$ & $7 / 290(2)$ & $16 / 307(5)$ & 0.46 (0.19 to 1.11$)$ & \\
\hline Pooled effect§ & 19/666 (3) & $32 / 676(5)$ & 0.61 (0.35 to 1.05$)$ & 0.62 (0.35 to 1.08$)$ \\
\hline \multicolumn{5}{|l|}{ Intraluminal recurrences } \\
\hline Makela et al, $1995^{17}$ & $2 / 52(4)$ & $1 / 54(2)$ & 2.08 (0.19 to 22.2) & \\
\hline Ohlsson et al, $1995^{18}$ & $2 / 53(4)$ & $2 / 54(4)$ & 1.02 (0.15 to 6.97$)$ & \\
\hline Schoemaker et al, $1998^{19}$ & $3 / 167(2)$ & $5 / 158(3)$ & 0.57 (0.14 to 2.34$)$ & \\
\hline Pietra et al, $1998^{20}$ & $1 / 104(1)$ & $1 / 103(1)$ & 0.99 (0.06 to 15.6$)$ & \\
\hline Subgroup $\ddagger$ & $8 / 376(2.1)$ & 9/367 (2.5) & 0.88 (0.34 to 2.23$)$ & 0.87 (0.33 to 2.28$)$ \\
\hline Kjeldsen et al, $1997^{21}$ & $10 / 134(7)$ ๆ & 6/149 (4) ๆ & 1.85 (0.69 to 4.96$)$ & \\
\hline Pooled effect§ & $18 / 510(3.5)$ & $15 / 518(2.8)$ & 1.25 (0.64 to 2.44$)$ & 1.26 (0.63 to 2.51$)$ \\
\hline \multicolumn{5}{|l|}{ Metachronous cancers } \\
\hline Makela et al, $1995^{17}$ & $1 / 52(2)$ & $0 / 54(0)$ & 3.11 (0.13 to 74.7$)$ & \\
\hline
\end{tabular}




\begin{tabular}{|c|c|c|c|c|}
\hline & Intensive follow up & Control follow up & Fixed effects* & Random effects $\dagger$ \\
\hline Ohlsson et al, $1995^{18}$ & $0 / 53(0)$ & $1 / 54(2)$ & 0.34 (0.01 to 8.15) & \\
\hline Schoemaker et al, $1998^{19}$ & 3/167 (2) & 2/158 (1) & $1.42(0.24 .8 .38)$ & \\
\hline Pietra et al, $1998^{20}$ & 0/104 (0) & 1/103 (1) & 0.33 (0.01 to 8.01) & \\
\hline Subgroup $\neq$ & 4/376 (1.1) & 4/367 (1.1) & 0.98 (0.30 to 3.19$)$ & 1.01 (0.28 to 3.63$)$ \\
\hline Kjeldsen et al, $1997^{21}$ & $7 / 290(2)$ & 3/307 (1) & 2.47 (0.64 to 9.46$)$ & \\
\hline Pooled effect§ & $11 / 666$ (1.7) & $7 / 676(1.0)$ & 1.50 (0.63 to 3.54$)$ & $1.55(0.28$ to 3.63$)$ \\
\hline
\end{tabular}

*Mantel and Haenszel.

†DerSimonian and Laird.

fExtramural detection trials.

Extramural and intramural detection trials.

१Data based on rectal cancers only.

mortality of $9-13 \%$. This improvement compares favourably with, for instance, the $5 \%$ benefit observed for adjuvant chemotherapy in Dukes' stage C disease $^{4-29}$ and is applicable to a wider range of clinical stages of colorectal cancer. ${ }^{30}$ In addition, the trials we included predated multidisciplinary approaches to the treatment of colorectal cancer, including the wider practice of hepatic resections for metastases, pelvic exenterations for recurrent pelvic disease, and the use of combined therapies for advanced disease. These approaches influence survival, ${ }^{4}$ and the potential survival benefits from intensive follow up may be even greater than those expressed in this analysis. ${ }^{30}$

\section{Quality of trials}

The quality of included studies should be considered in the interpretation of our findings. None of the trials reported adequate concealment of allocation nor com- prehensive blinding of outcome assessment. Only two studies stated that randomisation was stratified for major prognostic factors. Despite these shortcomings, the strength of the present analysis is that it was limited to randomised controlled trials and that it supersedes previous meta-analyses, which were based on predominantly retrospective data. ${ }^{9}$

\section{Mechanisms and future trials}

Intensive follow up may improve survival in people with colorectal cancer because of earlier detection and treatment of recurrent disease. It may also be associated with non-specific factors, such as improved psychological wellbeing in patients. The detection rates in this analysis for all local recurrences and hepatic metastases were similar to those quoted in the literature, ${ }^{31-33}$ but intensive follow up was associated with a reduced time to first relapse and increased

Table 4 Mean (SD) time (months) to first relapse in patients with colorectal cancer according to intensive or control follow up

\begin{tabular}{lccc} 
& Intensive follow up & Control follow up & Differences in means (95\% Cl) \\
\hline Makela et al, $1995^{17}$ & $10.0(5.0)$ & $15.0(10.0)$ & $-5.00(-7.99$ to -2.01$)$ \\
\hline Ohlsson et al, $1995^{18}$ & $20.4(8.0)^{*}$ & $24.0(7.0)^{*}$ & $-3.60(-6.45$ to -0.75$)$ \\
\hline Schoemaker et al, $1998^{19}$ & Not stated & \\
\hline Pietra et al, $1998^{20}$ & $10.3(2.7)$ & $20.2(6.1)$ & $-9.90(-11.19$ to -8.61$)$ \\
\hline Subgroup $†$ & & & $-8.32(-9.41$ to -7.23$)$ \\
\hline Kjeldsen et al, $1997^{21}$ & $17.7(8) \S$ & $26.5(8.0) \S$ & $-8.80(-10.25$ to -7.35$)$ \\
\hline Pooled effect $¥$ & & & $-8.50(-9.37$ to -7.62$)$
\end{tabular}

*Estimated from ranges stated.

†Extramural detection trials.

łExtramural and intramural detection trials.

$\S$ Estimated from geometric curves.

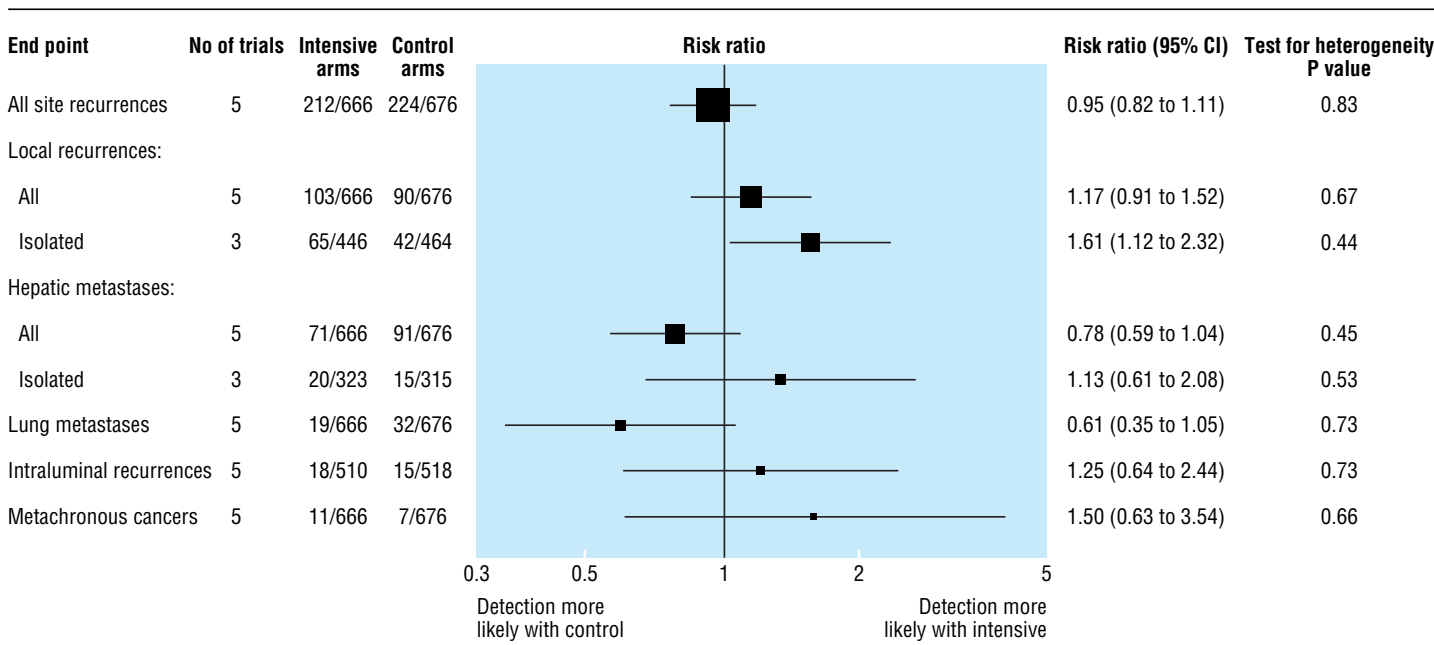

Fig 4 Pooled data and summary risk ratios (fixed effects method) for recurrences, metastases, and metachronous (second colorectal primary) cancers 


\section{What is already known on this topic}

There is a lack of direct evidence that intensive follow up after initial curative treatment for colorectal cancer leads to increased survival

Guidelines are inconclusive and clinical practice varies widely

\section{What this study adds}

The cumulative analysis of available data supports the view that intensive follow up after curative resection for colorectal cancer improves survival

If computed tomography and frequent measurements of serum carcinoembryonic antigen are used during follow up mortality related to cancer is reduced by $9-13 \%$

This survival benefit is partly attributable to the earlier detection of all recurrences, particularly the increased detection of isolated recurrent disease

detection of isolated local recurrences. This lends support to the former hypothesis. The importance of psychological factors remains unclear for patients with colorectal cancer. The GIVIO study showed that increased psychological support influences survival in patients with breast cancer but not in those with colorectal cancer. ${ }^{34}$ On the other hand, increased psychological support may influence outcome in particular groups of patients with gastrointestinal cancer. $^{35}$

Many clinicians favour colonoscopic surveillance (intramural detection) over investigations aimed at the detection of extramural recurrences. ${ }^{6}{ }^{8}$ Our findings show that this is not justified. As seen in previous studies $^{36}{ }^{37}$ we found that intraluminal recurrences and metachronous cancers were uncommon, irrespective of the intensity of follow up. Therefore, intensive efforts directed at the detection of intraluminal disease are probably of low benefit. We could not address the impact on outcome of intensive follow up through the detection of adenomas, known precursors of malignancy, but increasingly it is recognised that screening for adenomas is most beneficial in those aged 55-65 years. ${ }^{38}$ For many patients with colorectal cancer this opportunity may have passed.

We could not evaluate the efficacy of individual investigations used in colorectal cancer surveillance. This review represents a pragmatic evaluation of two broad strategies of surveillance. Future large multicentre trials should use a factorial design to allow separation of the effects of different tests performed during follow up. Application of the principles of intensive follow up in this common cancer has potentially important financial and resource implications for health services. Although estimation of the cost per life years gained is beyond the scope of this paper, the present study should serve as a basis for economic modelling in future trials. Finally, while wide variation in follow up persists in clinical practice, we believe that clinical guidelines should be revised.

Contributors: AGR and STO'D initiated the initial design of this study. AGR and MPS undertook the literature search and data extraction. ME advised on the literature search and performed quality assessments and statistical analyses. All authors contributed to the writing of the final draft of the manuscript. STO'D is guarantor.

Funding: None.

Competing interests: None declared.

1 Pisani P, Parkin DM, Bray F, Ferlay J. Estimates of the worldwide mortality from 25 cancers in 1990. Int J Cancer 1999:83:18-29.

2 Abulafi AM, Williams NS. Local recurrence of colorectal cancer: the problem, mechanisms, management and adjuvant therapy. Br J Surg 1994;81:7-19.

3 Waghorn A, Thompson J, McKee M. Routine surgical follow up: do surgeons agree? BMJ 1995;311:1344-5.

4 Association of Coloproctology of Great Britain and Ireland. Guidelines for the management of colorectal cancer. London: Association of Coloproctology of Great Britain and Ireland, 2001.

5 Scotland Intercollegiate Guidelines Network. Clinical guidelines for colorectal cancer. 1997. www.sugn.ac.uk/guidelines/published/index.html (accessed Feb 2002).

6 Mella J, Datta SN, Biffin A, Radcliffe AG, Steele RJ, Stamatakis JD. Surgeons' follow-up practice after resection of colorectal cancer. Ann $R$ Coll Surg Engl 1997;79:206-9.

7 Bruinvels DJ, Stiggelbout AM, Klaassen MP, Kievit J, Dik J, Habbema F, et al. Follow-up after colorectal cancer: current practice in the Netherlands. Eur J Surg 1995;161:827-31.

8 Virgo KS, Wade TP, Longo WE, Coplin MA, Vernava AM, Johnson FE Surveillance after curative colon cancer resection: practice patterns of surgical subspecialists. Ann Surg Oncol 1995;2:472-82

9 Bruinvels DJ, Stiggelbout AM, Kievit J, van Houwelingen HC, Habbema JD, van de Velde CJ. Follow-up of patients with colorectal cancer. A metaanalysis. Ann Surg 1994;219:174-82

10 Rosen M, Chan L, Beart RW Jr, Vukasin P, Anthone G. Follow-up of colorectal cancer: a meta-analysis. Dis Colon Rectum 1998;41:1116-26.

11 Lefebrve A, Clarke M. Identifying randomised trials. In: Egger M, Davey Smith G, Altman DG. Systematic reviews in health care:meta-analysis in context. London: BMJ Publishing, 2001:69-86.

12 Jüni P, Altman DG, Egger M. Systematic reviews in health care: assessing the quality of controlled clinical trials. BMJ 2001;323:42-6.

13 Deeks JJ, Altman DG, Bradburn MJ. Statistical methods for examining heterogeneity and combining results from several studies in metaanalysis. In: Egger M, Davey-Smith G, Altman DG. Systematic reviews in health care: meta-analysis in context. London: BMJ Publishing, 2001:285312

14 DerSimonian R, Laird N. Meta-analysis in clinical trials. Control Clin Trials $1986 ; 7: 177-88$

15 Egger M, Davey Smith G, Schneider M, Minder C. Bias in meta-analysis detected by a simple, graphical test. BMJ 1997;315:629-34.

16 Thompson SG, Sharp S. Explaining heterogeneity in meta-analysis: a comparison of methods. Stat Med 1999;18:2693-708

17 Makela JT, Laitinen SO, Kairaluoma MI. Five-year follow-up after radical surgery for colorectal cancer. Results of a prospective randomized trial. Arch Surg 1995;130:1062-7.

18 Ohlsson B, Breland U, Ekberg H, Graffner H, Tranberg KG. Follow-up after curative surgery for colorectal carcinoma. Randomized comparison with no follow-up. Dis Colon Rectum 1995;38:619-26.

19 Schoemaker D, Black R, Giles L, Toouli J. Yearly colonoscopy, liver CT, and chest radiography do not influence 5-year survival of colorectal cancer patients. Gastroenterology 1998;114:7-14.

20 Pietra N, Sarli L, Costi R, Ouchemi C, Grattarola M, Peracchia A. Role of follow-up in management of local recurrences of colorectal cancer: a prospective, randomized study. Dis Colon Rectum 1998;41:1127-33.

21 Kjeldsen BJ, Kronborg O, Fenger C, Jorgensen OD. A prospective randomized study of follow-up after radical surgery for colorectal cancer. Br J Surg 1997;84:666-9.

22 Northover J, Houghton J, Lennon T. CEA to detect recurrence of colon cancer. JAMA 1994;272:31.

23 Barillari P, Ramacciato G, Manetti G, Bovino A, Sammartino P, Stipa V. Surveillance of colorectal cancer: effectiveness of early detection of intraluminal recurrences on prognosis and survival of patients treated for cure. Dis Colon Rectum 1996:39:388-93.

24 Kronborg O, Fenger C, Deichgraber E, Hansen L. Follow-up after radical surgery for colorectal cancer. Design of a randomized study. Scand J Gastroenterol Suppl 1988;149:159-62

25 Makela J, Laitinen S, Kairaluoma MI. Early results of follow-up after radical resection for colorectal cancer. Preliminary results of a prospective randomized trial. Surg Oncol 1992;1:157-61.

26 McCall JL, Black RB, Rich CA, Harvey JR, Baker RA, Watts JM, et al. The value of serum carcinoembryonic antigen in predicting recurrent disease following curative resection of colorectal cancer. Dis Colon Rectum 1994;37:875-81.

27 Kjeldsen BJ, Kronborg O, Fenger C, Jorgensen OD. The pattern of recurrent colorectal cancer in a prospective randomised study and the characteristics of diagnostic tests. Int J Colorectal Dis 1997;12:329-34.

28 Kjeldsen BJ, Thorsen H, Whalley D, Kronborg O. Influence of follow-up on health-related quality of life after radical surgery for colorectal cancer. Scand J Gastroenterol 1999;34:509-15.

29 Dube S, Heyen F, Jenicek M. Adjuvant chemotherapy in colorectal carcinoma: results of a meta-analysis. Dis Colon Rectum 1997;40:35-41.

30 Renehan AG, O'Dwyer ST. Surveillance after colorectal cancer resection [letter]. Lancet 2000;355:1095-6.

31 Malcolm AW, Perencevich NP, Olson RM, Hanley JA, Chaffey JT, Wilson RE. Analysis of recurrence patterns following curative resection for carcinoma of the colon and rectum. Surg Gynecol Obstet 1981;152:131-6. 
32 Phillips RK, Hittinger R, Blesovsky L, Fry JS, Fielding LP. Large bowel cancer: surgical pathology and its relationship to survival. $\mathrm{Br} J$ Surg 1984;71:604-10

33 Willett CG, Tepper JE, Cohen AM, Orlow E, Welch CE. Failure patterns following curative resection of colonic carcinoma. Ann Surg 1984;200:685-90.

34 GIVIO Investigators. Impact of follow-up testing on survival and healthrelated quality of life in breast cancer patients. A multicenter randomized controlled trial. JAMA 1994;271:1587-92.

35 Kuchler T, Henne-Bruns D, Rappat S, Graul J, Holst K, Williams JI, et al. Impact of psychotherapeutic support on gastrointestinal cancer patients undergoing surgery: survival results of a trial. Hepatogastroenterology 1999;46:322-35.

36 Lockhart-Mummery HE, Heald RJ. Metachronous cancer of the large intestine. Dis Colon Rectum 1972;15:261-4.

37 Cunliffe WJ, Hasleton PS, Tweedle DE, Schofield PF. Incidence of synchronous and metachronous colorectal carcinoma. Br J Surg 1984;71:941-3.

38 Atkin WS, Cuzick J, Northover JM, Whynes DK. Prevention of colorectal cancer by once-only sigmoidoscopy. Lancet 1993;341:736-40.

(Accepted 7 November 2001) 